\title{
Peak expiratory flow rate of Nepalese children and young adults
}

\author{
Dhungel KU ${ }^{1}$, Parthasarathy $\mathbf{D}^{2}$, Dipali $\mathrm{S}^{3}$
}

${ }^{1}$ Lecturer, Department of Physiology, Nepal Medical College, Kathmandu, Nepal, ${ }^{2}$ Assistant Professor, ${ }^{3}$ Professor, Department of Physiology, Manipal College of Medical Sciences, Pokhara, Nepal

\begin{abstract}
Introduction: In diagnosis and treatment of respiratory diseases, the assessment of lung functions is of considerable importance. So, normal reference values for pulmonary function tests of any population need to be assessed.

Objective: An attempt has been made in the present study to measure the peak expiratory flow rate (PEFR) in healthy Nepalese children and young adults.

Material and methods: One hundred ninety six (196) students were selected by inclusion criteria from different schools and colleges in Pokhara Sub- Metropolitan City, Nepal. The anthropometric measurements and peak expiratory flow rate (PEFR) were measured by standard procedures.

Result: The mean PEFR values of males and females are found to have $350.3( \pm 135.0) 1 . \mathrm{min}^{-1}$ and $280.2( \pm 98.77) 1$. $\min ^{-1}$ respectively. The PEFR values of Nepalese males of the present study are found to be higher as compared to their females' counterparts. It is interestingly noted that at preadolescence time, PEFR is almost comparable in both sexes but after puberty males attained significantly higher values than females. The trend of PEFR values with development of the age is also been noted. It is interestingly pointed out that PEFR values of Nepalese males in the present study increases significantly with the advancement of age up to 20 years of age and then after PEFR do not change. On the other hand, females showed significant PEFR increment with the advancement of age up to 15 years of age only and then after PEFR do not improve significantly.

Conclusion: PEFR was found to be influenced significantly by height not by the weight. Finally, a prediction equation was established by which PEFR of Nepalese population of 5 to 25 years of age can be estimated from age or height.
\end{abstract}

Keywords: Peak expiratory flow rate, Nepalese children, Growth \& Development, sex difference and obesity

$\mathrm{D}$ isease of respiratory system accounts for up to a third of deaths in most countries ${ }^{1}$. In diagnosis and treatment of respiratory diseases, the assessment of lung functions is of considerable importance, key tests being vital capacity (VC), forced vital capacity (FVC), maximum expiratory flow rate (MEFR) or peak expiratory flow rate (PEFR), maximum ventilatory volume (MVV) ${ }^{2}$. So, normal reference values for lung function tests of any population need to be assessed. PEFR measurement by peak flow meter is an easy way to measure lung functions in field study ${ }^{3}$. PEFR is the maximum rate of airflow achieved during a forced expiration after maximal inspiration ${ }^{2,3}$. Lung functions including PEFR are affected by various factors such as sex, body surface area, physical activity, posture, environment, racial differences etc ${ }^{5,6,7,8}$.

However, there is scanty of literature about PEFR in Nepalese population. Only one study was found from Medline Search. It was on PEFR of Nepalese females with smoking habit ${ }^{9}$. No such study was found on Nepalese normal children and adults. On the other hand
Peak flow meter is an easy and cost effective instrument by which PEFR can be measured. For different respiratory disease treatment, routine lung functions measurement is required to follow up the patients. And for this reason PEFR is one of the best choices. However, it is very much important to know the standard lung function values of Nepalese populations. So, an attempt has been made in the present study i) to measure the PEFR in healthy Nepalese children and young adults, ii) to observe the effect of growth and development on PEFR, and iii) to evaluate the effect of body size and obesity on PEFR.

\section{Materials and methods}

The present study was conducted in different schools and colleges in Pokhara Sub- Metropolitan City, Nepal. Two

\footnotetext{
Correspondence

Kshitiz Upadhyay Dhungel

Department of Physiology

Nepal Medical College

Kathmandu, Nepal

Email: kistiz2003@hotmail.com
} 
hundred and fifty one (251) students participated in the present study. A self- designed questionnaire was used to take medical, physical activity history and smoking status. All the participants filled the questionnaire form and it was verified thoroughly by interview. Out of 251 participants, who filled the form, 196 students, was selected by the inclusion criteria for the study. Inclusion criteria includes: no smoking history; living with sedentary lifestyle and no regular physical training, sports activity, no history of any respiratory disease as bronchitis, pneumonia, tuberculosis, asthma, etc. during the previous three years and at the time of the test; no persistent cough/phlegm, hemoptysis, dyspnoea wheezing or nasal catarrh at the time of the study.

After selection of the subjects by above mentioned inclusion criteria, subjects were grouped according to their age and sex. The age groups are Group-I, 5-10 years; Group-II, 11-15 years; Group-III, 16-20 years; GroupIV, 21-25 years. The anthropometric measurements such as height, weight, waist circumference, hip circumference, thigh circumference were measured by standard procedures. Body surface area (BSA), body mass index (BMI), waist-hip ratio (WHR), waistthigh ratio (WTR), were calculated by the standard anthropometric measurements.

\section{Body mass index (BMI)}

BMI was calculated from height and weight of the subject by using following formulae.

$\mathrm{BMI}=$ weight $(\mathrm{kg}) /$ height $(\mathrm{m})^{2}$.

\section{Body surface area (BSA)}

BSA was calculated by using Dubois' Formula $^{10}$ as follows.

BSA $\left(\mathrm{m}^{2}\right)=$ weight $(\mathrm{kg})^{0.425} \times$ height $(\mathrm{cm})^{0.725} \times$ 0.007184 .

\section{Peak expiratory flow rate (PEFR)}

PEFR was measured in standing position with "standard range FERRARIS Pocket Peak flow meter" manufactured by Ferraris Medical Ltd. London as used in other studies ${ }^{11,12}$. The subjects were made relaxed before taking the reading. The test procedure was explained to the subjects and a demonstration of maneuver was given to each of the subjects. After proper rest, subject was requested to take a deep breath and exhale as forcefully as possible in one single blow into the instrument with their nose closed. Three satisfactory reading were taken and highest of the three was accepted ${ }^{13,14}$. Close watch was made to ensure that a tight seal was maintained between lips and mouthpiece of the peak flow meter. The PEFR was recorded nearest to $1 / \mathrm{min}$.

\section{Statistical analysis}

After data collection, data analysis was performed using Microsoft Excel and Statistical package for social sciences (SPSS, version 10.0). Mean, standard deviation (SD), minimum value, maximum value, were obtained for all the selected variables of healthy Nepalese children and adults. All the subject of the present study are grouped into four sub-groups according to their age as Group-I, 5-10 years; Group-II, 11-15 years; GroupIII, 16-20 years; Group-IV, 21-25 years. One way ANOVA was done to examine any difference between the variables in each group. Independent t-test was also performed to see the differences of mean of all variables in between males and females of all groups. Pearson's product moment correlation coefficient was performed to examine the relation of age, weight, height, BMI, BSA, WHR, and WTR with PEFR. Partial correlation coefficient was also performed for different variables with PEFR. Linear regression analysis was performed to see the relationship between PEFR and age and also with PEFR and height.

\section{Results}

Comparisons of physical characteristics and PEFR of the males and females of the present study are shown in Table 1. Among the physical characteristics, height, BSA, WHR, WTR of males are significantly $(\mathrm{p}<0.05)$ higher than that of females. The mean value of PEFR of males is also significantly $(p<0.05)$ higher than that of females.

The physical characteristics and PEFR of the subjects of different age groups are compared in Table 2 and 3 respectively. All the physical characteristic variables and PEFR differed significantly $(\mathrm{p}<0.05)$ among different age groups in both the sexes.

On the other hand the comparisons of physical characteristics and PEFR of males and females of different age groups are presented in Fig 1 and Table 4. The PEFR values of the males were significantly higher than females only in 16-20 and 21-25 years age groups. The mean PEFR of the males of the present study significantly increased from 5 to 20 years of age and after that no such increment was found up to 25 years of age. On the other hand females showed significant increment in PEFR from 5 to 15 years of age and after that there was a plateau observed up to 25 years of age (Fig 1).

Pearson product moment correlation of PEFR with physical characteristics of the males and females of the present study are presented in Table 5. It was observed that all the physical characteristics including the age were positively and significantly $(p<0.01)$ correlated 
with PEFR in both males and females except WHR \& WTR, which were negatively and significantly correlated.

Beside that, partial correlation coefficients of PEFR with physical characteristics of the subjects of the present study are presented in Table 6. Age of the subjects (both males and females) was significantly ( $\mathrm{p}<$ 0.01) correlated with PEFR when BMI was partialed out (Males $\boldsymbol{r}, 0.77$; Females $\boldsymbol{r}, 0.38$ ). BSA of the subjects was significantly $(p<0.01)$ correlated with PEFR when age was controlled (Males $\boldsymbol{r}, 0.68$; Females $\boldsymbol{r}, 0.63$ ). Height of the subjects was significantly correlated with PEFR when weight was partialed out (Males $r, 0.42$; Females $\boldsymbol{r}, 0.43$ ). But it was interestingly noted that weight of the subjects was not significantly correlated when height was partialed out.
Body mass index (BMI), which is an important variable to measure overweight of the subjects, was significantly $(\mathrm{P}<0.01)$ and positively correlated with PEFR (Males $\boldsymbol{r}$, 0.45 ; Females $\boldsymbol{r}, 0.32$ ) in both the sexes, when age was partialed out. On the other hand WHR and WTR, which are the important indices to measure central obesity, were significantly $(\mathrm{P}<0.01)$ but negatively correlated with PEFR when BMI was controlled (WTR: Males $\boldsymbol{r}$, - 0.18; Females $\boldsymbol{r},-0.19$, WHR: Males $\boldsymbol{r},-0.03$; Females $r,-0.27)$.

The results of the linear regression analysis depicting the prediction of PEFR (1.min ${ }^{-1}$ ) from age (years), and height $(\mathrm{cm})$ of males and females are shown from Fig. 2 through 5 .

Table 1: Comparison of physical characteristics and peak expiratory flow rate (PEFR) of the males and females of the present study

\begin{tabular}{|l|c|c|c|}
\hline Variables & $\begin{array}{c}\text { Males } \\
(\mathbf{n}, \mathbf{9 9})\end{array}$ & $\begin{array}{c}\text { Females } \\
(\mathbf{n}, \mathbf{9 7})\end{array}$ & $\begin{array}{c}\text { F-value with level of signifi- } \\
\text { cance }\end{array}$ \\
\hline Age $($ years $)$ & $14.5 \pm 5.16$ & $14.6 \pm 5.30$ & $0.25^{\text {ns }}$ \\
\hline Weight $(\mathrm{kg})$ & $44.1 \pm 16.66$ & $43.3 \pm 14.72$ & $6.19^{\mathrm{ns}}$ \\
\hline Height $(\mathrm{cm})$ & $147.9 \pm 20.93$ & $142.7 \pm 16.05$ & $22.73^{*}$ \\
\hline BSA $\left(\mathrm{m}^{2}\right)$ & $1.3 \pm 0.35$ & $1.3 \pm 0.29$ & $13.29^{*}$ \\
\hline BMI $\left(\mathrm{kg} / \mathrm{m}^{2}\right)$ & $19.2 \pm 3.24$ & $20.5 \pm 3.73$ & $0.25^{\mathrm{ns}}$ \\
\hline WTR & $1.6 \pm 0.15$ & $1.6 \pm 0.20$ & $13.64^{*}$ \\
\hline WHR & $0.8 \pm 0.01$ & $0.8 \pm 0.01$ & $9.99^{*}$ \\
\hline PEFR $\left(1 . \mathrm{min}^{-1}\right)$ & $350.3 \pm 135.00$ & $280.2 \pm 98.77$ & $20.86^{*}$ \\
\hline
\end{tabular}

SD, standard deviation; BMI, Body mass Index; WTR, waist-thigh ratio; WHR, waist-hip ratio; PEFR, Peak expiratory flow rate; ${ }^{*}, \mathrm{p}<0.05$; ns, non significant.

Table 2: Comparision of physical characteristics and peak expiratory flow rate (PEFR) of the males of different age groups of the present study

\begin{tabular}{|l|c|c|c|c|c|}
\hline Variables & $\begin{array}{c}\text { Group-I } \\
\mathbf{( n , 2 9 )}\end{array}$ & $\begin{array}{c}\text { Group-II } \\
\mathbf{( n , 3 1 )}\end{array}$ & $\begin{array}{c}\text { Group-III } \\
\mathbf{( n , 2 2 )}\end{array}$ & $\begin{array}{c}\text { Group-IV } \\
\mathbf{( n , 1 7 )}\end{array}$ & $\begin{array}{c}\text { F-value with level } \\
\text { of significance }\end{array}$ \\
\hline Age $($ years) & $8.5 \pm 1.12$ & $13.2 \pm 1.57$ & $18.2 \pm 1.47$ & $22.3 \pm 1.26$ & $423.9^{* *}$ \\
\hline Height $(\mathrm{cm})$ & $120.8 \pm 7.08$ & $150.2 \pm 14.28$ & $166.5 \pm 5.34$ & $165.8 \pm 3.86$ & $131.15^{* *}$ \\
\hline Weight $(\mathrm{kg})$ & $23.8 \pm 4.32$ & $45.1 \pm 12.41$ & $58.5 \pm 8.37$ & $58.2 \pm 6.60$ & $86.13^{* *}$ \\
\hline BSA $\left(\mathrm{m}^{2}\right)$ & $0.9 \pm 0.10$ & $1.4 \pm 0.25$ & $1.7 \pm 0.11$ & $1.6 \pm 0.01$ & $117.85^{* *}$ \\
\hline BMI $\left(\mathrm{kg} / \mathrm{m}^{2}\right)$ & $16.2 \pm 1.54$ & $19.6 \pm 2.85$ & $21.1 \pm 3.10$ & $21.2 \pm 2.52$ & $21.27^{* *}$ \\
\hline WTR & $1.7 \pm 0.19$ & $1.5 \pm 0.13$ & $1.5 \pm 0.09$ & $1.6 \pm 0.08$ & $6.05^{* *}$ \\
\hline WHR & $0.9 \pm 0.06$ & $0.8 \pm 0.04$ & $0.8 \pm 0.03$ & $0.8 \pm 0.04$ & $5.46^{* *}$ \\
\hline PEFR $\left(1 . \mathrm{min}^{-1}\right)$ & $189.3 \pm 40.70$ & $342.9 \pm 90.70$ & $481.8 \pm 55.08$ & $468.2 \pm 58.12$ & $104.36^{* *}$ \\
\hline
\end{tabular}

Values are mean $\pm \mathrm{SD}$;**, $<<0.01$; Group-I, 5-10 years; Group-II, 11-15 years; Group-III, 16-20 years; Group-IV, 21-25 years; n, number of subjects; BMI, Body mass Index; WTR, waist-thigh ratio; WHR, waist-hip ratio; PEFR, Peak expiratory flow rate 
Table 3: Comparision of physical characteristics and peak expiratory flow rate (PEFR) of the females of different age groups of the present Study

\begin{tabular}{|l|c|c|c|c|c|}
\hline Variables & $\begin{array}{c}\text { Group-I } \\
\mathbf{( n , 2 8 )}\end{array}$ & $\begin{array}{c}\text { Group-II } \\
\mathbf{( n , 3 4 )}\end{array}$ & $\begin{array}{c}\text { Group-III } \\
\mathbf{( n , 1 8 )}\end{array}$ & $\begin{array}{c}\text { Group-IV } \\
\mathbf{( n , 1 7 )}\end{array}$ & $\begin{array}{c}\text { F-value with level of } \\
\text { significance }\end{array}$ \\
\hline Age $($ years $)$ & $8.5 \pm 1.07$ & $13.9 \pm 1.15$ & $17.3 \pm 1.45$ & $23.5 \pm 1.28$ & $577.97^{* *}$ \\
\hline Height $(\mathrm{cm})$ & $120.4 \pm 9.80$ & $149.4 \pm 6.07$ & $154.6 \pm 2.97$ & $153.7 \pm 6.88$ & $130.69^{* *}$ \\
\hline Weight $(\mathrm{kg})$ & $23.8 \pm 4.81$ & $49.9 \pm 9.22$ & $51.2 \pm 5.98$ & $53.9 \pm 10.11$ & $82.70^{* *}$ \\
\hline BSA $\left(\mathrm{m}^{2}\right)$ & $0.9 \pm 0.13$ & $1.4 \pm 0.14$ & $1.5 \pm 0.01$ & $1.5 \pm 0.15$ & $126.32^{* *}$ \\
\hline BMI $\left(\mathrm{kg} . \mathrm{m}^{2}\right)$ & $16.3 \pm 1.43$ & $22.2 \pm 3.20$ & $21.4 \pm 2.41$ & $22.7 \pm 2.87$ & $33.62^{* *}$ \\
\hline WTR & $1.7 \pm 0.13$ & $1.5 \pm 0.17$ & $1.5 \pm 0.25$ & $1.4 \pm 0.13$ & $11.95^{* *}$ \\
\hline WHR & $0.9 \pm 0.04$ & $0.8 \pm 0.06$ & $0.8 \pm 0.08$ & $0.8 \pm 0.06$ & $8.68^{* *}$ \\
\hline PEFR $\left(1 . \mathrm{min}^{-1}\right)$ & $170.4 \pm 47.87$ & $322.9 \pm 72.46$ & $327.8 \pm 66.82$ & $325.3 \pm 96.89$ & $31.94^{* *}$ \\
\hline
\end{tabular}

Values are mean $\pm \mathrm{SD}$; **, $\mathrm{p}<0.01$; Group-I,5-10 years; Group-II, 11-15 years; Group-III, 16 -20 years; Group-IV, 21-25 years; n, number of subjects; BMI, Body mass Index; WTR, waist-thigh ratio; WHR, waist-hip ratio; PEFR, Peak expiratory flow rate

Table 4: Comparision of Physical characteristics and peak expiratory flow rate (PEFR) of the males and females of different age groups of the present study

\begin{tabular}{|c|c|c|c|c|c|c|c|c|}
\hline \multirow[t]{2}{*}{ Variables } & \multicolumn{2}{|c|}{ Group-I } & \multicolumn{2}{|c|}{ Group-II } & \multicolumn{2}{|c|}{ Group-III } & \multicolumn{2}{|c|}{ Group-IV } \\
\hline & $\begin{array}{l}\text { Males } \\
(\mathbf{n}, 29)\end{array}$ & $\begin{array}{c}\text { Females } \\
(\mathbf{n}, 28)\end{array}$ & $\begin{array}{l}\text { Males } \\
(\mathbf{n}, \mathbf{3 1})\end{array}$ & $\begin{array}{c}\text { Females } \\
(n, 34)\end{array}$ & $\begin{array}{l}\text { Males } \\
(n, 22)\end{array}$ & $\begin{array}{c}\text { Females } \\
(\mathbf{n}, 18)\end{array}$ & $\begin{array}{l}\text { Males } \\
(\mathbf{n}, 17)\end{array}$ & $\begin{array}{c}\text { Females } \\
(\mathbf{n}, 17)\end{array}$ \\
\hline $\begin{array}{l}\text { Age } \\
\text { (years) }\end{array}$ & $\begin{array}{c}8.5 \\
\pm \\
1.12\end{array}$ & $\begin{array}{c}8.5 \\
\pm \\
1.07^{\mathrm{ns}}\end{array}$ & $\begin{array}{c}13.2 \\
\pm \\
1.57\end{array}$ & $\begin{array}{c}13.9 \\
\pm \\
1.15^{\mathrm{ns}}\end{array}$ & $\begin{array}{c}18.2 \\
\pm \\
1.47\end{array}$ & $\begin{array}{c}17.3 \\
\pm \\
1.45^{\mathrm{ns}}\end{array}$ & $\begin{array}{c}22.3 \\
\pm \\
1.26\end{array}$ & $\begin{array}{c}23.5 \\
\pm \\
1.28^{\mathrm{ns}}\end{array}$ \\
\hline $\begin{array}{l}\text { Height } \\
(\mathrm{cm})\end{array}$ & $\begin{array}{c}120.8 \\
\pm \\
7.08\end{array}$ & $\begin{array}{c}120.4 \\
\pm \\
9.80^{\mathrm{ns}}\end{array}$ & $\begin{array}{c}150.2 \\
\pm \\
14.28\end{array}$ & $\begin{array}{c}149.4 \\
\pm \\
6.07^{\mathrm{ns}}\end{array}$ & $\begin{array}{c}166.5 \\
\pm \\
5.34\end{array}$ & $\begin{array}{c}154.6 \\
\pm \\
2.97^{* *}\end{array}$ & $\begin{array}{c}165.8 \\
\pm \\
3.86\end{array}$ & $\begin{array}{c}153.7 \\
\pm \\
6.88^{* *}\end{array}$ \\
\hline $\begin{array}{l}\text { Weight } \\
(\mathrm{kg})\end{array}$ & $\begin{array}{c}23.8 \\
\pm \\
4.32\end{array}$ & $\begin{array}{c}23.8 \\
\pm \\
4.81^{\mathrm{ns}}\end{array}$ & $\begin{array}{c}45.1 \\
\pm \\
12.41\end{array}$ & $\begin{array}{c}49.9 \\
\pm \\
9.22^{\mathrm{ns}}\end{array}$ & $\begin{array}{c}58.5 \\
\pm \\
8.37\end{array}$ & $\begin{array}{c}51.2 \\
\pm \\
5.98^{* *}\end{array}$ & $\begin{array}{c}58.2 \\
\pm \\
6.60\end{array}$ & $\begin{array}{c}53.9 \\
\pm \\
10.11^{\mathrm{ns}}\end{array}$ \\
\hline $\operatorname{BSA}\left(\mathrm{m}^{2}\right)$ & $\begin{array}{c}0.9 \\
\pm \\
0.10\end{array}$ & $\begin{array}{c}0.9 \\
\pm \\
0.13^{\text {ns }}\end{array}$ & $\begin{array}{c}1.4 \\
\pm \\
0.25\end{array}$ & $\begin{array}{c}1.4 \\
\pm \\
0.14^{\mathrm{ns}}\end{array}$ & $\begin{array}{c}1.7 \\
\pm \\
0.11\end{array}$ & $\begin{array}{c}1.5 \\
\pm \\
0.01^{\mathrm{ns}}\end{array}$ & $\begin{array}{c}1.6 \\
\pm \\
0.01\end{array}$ & $\begin{array}{c}1.5 \\
\pm \\
0.15^{\mathrm{ns}}\end{array}$ \\
\hline $\begin{array}{l}\text { BMI }(\mathrm{kg} / \\
\left.\mathrm{m}^{2}\right)\end{array}$ & $\begin{array}{c}16.2 \\
\pm \\
1.54\end{array}$ & $\begin{array}{c}16.3 \\
\pm \\
1.43^{\mathrm{ns}}\end{array}$ & $\begin{array}{c}19.6 \\
\pm \\
2.85\end{array}$ & $\begin{array}{c}22.2 \\
\pm \\
3.20^{\mathrm{ns}}\end{array}$ & $\begin{array}{l}21.1 \\
\pm \\
3.10\end{array}$ & $\begin{array}{c}21.4 \\
\pm \\
2.41^{\mathrm{ns}}\end{array}$ & $\begin{array}{c}21.2 \\
\pm \\
2.52\end{array}$ & $\begin{array}{c}22.7 \\
\pm \\
2.87^{\mathrm{ns}}\end{array}$ \\
\hline WTR & $\begin{array}{c}1.7 \\
\pm \\
0.19\end{array}$ & $\begin{array}{c}1.7 \\
\pm \\
0.13^{\text {ns }}\end{array}$ & $\begin{array}{c}1.5 \\
\pm \\
0.13\end{array}$ & $\begin{array}{c}1.5 \\
\pm \\
0.17^{\text {ns }}\end{array}$ & $\begin{array}{c}1.5 \\
\pm \\
0.09\end{array}$ & $\begin{array}{c}1.5 \\
\pm \\
0.25^{\mathrm{ns}}\end{array}$ & $\begin{array}{c}1.6 \\
\pm \\
0.08\end{array}$ & $\begin{array}{c}1.4 \\
\pm \\
0.13^{* *}\end{array}$ \\
\hline WHR & $\begin{array}{c}0.9 \\
\pm \\
0.06\end{array}$ & $\begin{array}{c}0.9 \\
\pm \\
0.04^{\mathrm{ns}}\end{array}$ & $\begin{array}{c}0.8 \\
\pm \\
0.04\end{array}$ & $\begin{array}{c}0.8 \\
\pm \\
0.06^{*}\end{array}$ & $\begin{array}{c}0.8 \\
\pm \\
0.03\end{array}$ & $\begin{array}{c}0.8 \\
\pm \\
0.08^{\mathrm{ns}}\end{array}$ & $\begin{array}{c}0.8 \\
\pm \\
0.04\end{array}$ & $\begin{array}{c}0.8 \\
\pm \\
0.06^{\mathrm{ns}}\end{array}$ \\
\hline $\begin{array}{l}\text { PEFR } \\
\left(1 . \mathrm{min}^{-1}\right)\end{array}$ & $\begin{array}{c}189.3 \\
\pm \\
40.70\end{array}$ & $\begin{array}{c}170.4 \\
\pm \\
47.87^{\mathrm{ns}}\end{array}$ & $\begin{array}{c}342.9 \\
\pm \\
90.70\end{array}$ & $\begin{array}{c}322.9 \\
\pm \\
72.46^{\mathrm{ns}}\end{array}$ & $\begin{array}{c}481.8 \\
\pm \\
55.08\end{array}$ & $\begin{array}{c}327.8 \\
\pm \\
66.82^{* *}\end{array}$ & $\begin{array}{c}468.2 \\
\pm \\
58.12\end{array}$ & $\begin{array}{c}325.3 \\
\pm \\
96.89^{* *}\end{array}$ \\
\hline
\end{tabular}

Values are mean $\pm \mathrm{SD} ; \mathrm{t}$ test were performed to see the comparison of the males and females in different age groups. *, $\mathrm{p}<0.05 ; * *, \mathrm{p}<0.01 ;$ Group-I, 5-10 years; Group-II, 11-15 years; Group-III, 16-20 years; Group-IV, 21-25 years; n, number of subjects; BMI, Body mass Index; WTR, waist-thigh ratio; WHR, waist-hip ratio; PEFR, Peak expiratory flow rate 
Table 5: Pearson product moment correlation of PEFR with physical characteristics of the study subjects of the present study

\begin{tabular}{|l|c|c|}
\hline Variables & \multicolumn{2}{|c|}{ Correlation coefficient with level of significance } \\
\hline & Male $(\mathbf{n}, \mathbf{9 9})$ & Female (n, 97) \\
\hline Age $($ years $)$ & $0.86^{* *}$ & $0.59^{* *}$ \\
\hline Height $(\mathrm{cm})$ & $0.91^{* *}$ & $0.79^{* *}$ \\
\hline Weight $(\mathrm{kg})$ & $0.90^{* *}$ & $0.74^{* *}$ \\
\hline BSA $\left(\mathrm{m}^{2}\right)$ & $0.92^{* *}$ & $0.78^{* *}$ \\
\hline BMI $(\mathrm{kg} / \mathrm{m} 2)$ & $0.69^{* *}$ & $0.56^{* *}$ \\
\hline WTR & $-0.36^{* *}$ & $-0.35^{* *}$ \\
\hline WHR & $-0.26^{*}$ & $-0.31^{* *}$ \\
\hline
\end{tabular}

${ }^{*} \mathrm{P}<0.05 ;{ }^{* *} \mathrm{P}<0.01$ level

Table 6: Partial correlation coefficient of peak expiratory flow rate (PEFR) with physical characteristics of present study

\begin{tabular}{|l|c|c|c|}
\hline \multirow{2}{*}{ Variables } & \multicolumn{2}{|c|}{ Partial correlation coefficient with PEFR } & \multirow{2}{*}{$\begin{array}{c}\text { Variable } \\
\text { which is partialed out }\end{array}$} \\
\cline { 2 - 4 } & Male & Female & BMI \\
\hline Age $($ years $)$ & $0.77^{* *}$ & $0.38^{* *}$ & Weight \\
\hline Height $(\mathrm{cm})$ & $0.42^{* *}$ & $0.43^{* *}$ & Height \\
\hline Weight $(\mathrm{kg})$ & $0.36^{\text {ns }}$ & $0.08^{\text {ns }}$ & Age \\
\hline BSA $\left(\mathrm{m}^{2}\right)$ & $0.68^{* *}$ & $0.63^{* *}$ & Age \\
\hline BMI $(\mathrm{kg} / \mathrm{m} 2)$ & $0.45^{* *}$ & $0.32^{* *}$ & BMI \\
\hline WTR & $-0.18^{* *}$ & $-0.19^{* *}$ & BMI \\
\hline WHR & $-0.03^{* *}$ & $-0.27^{* *}$ & \\
\hline
\end{tabular}

${ }^{* *} \mathrm{P}<0.01$; ${ }^{\mathrm{ns}}$, non-significant

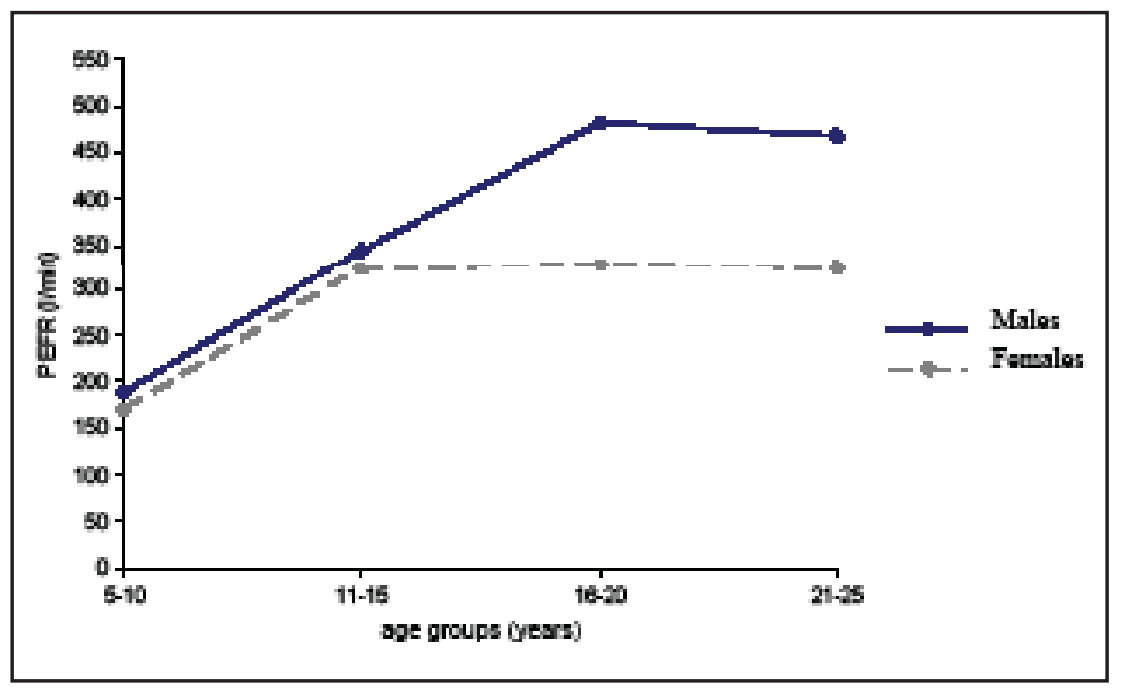

Fig 1: Comparison of PEFR (1/min) of males and females of different age groups of the present study 


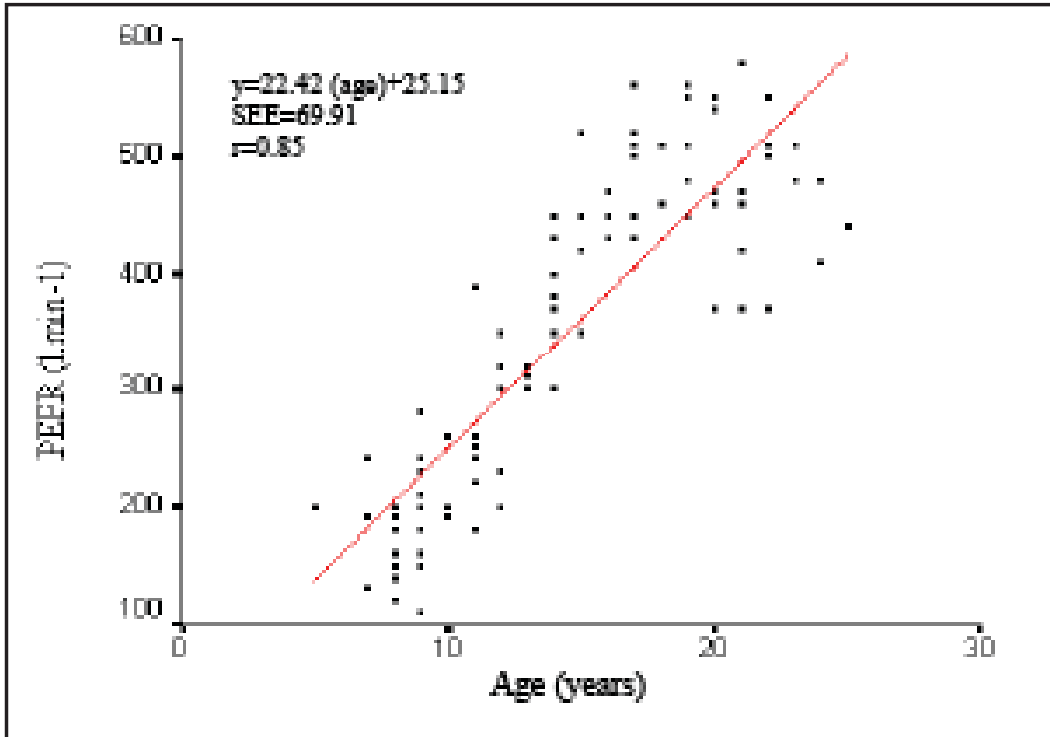

Fig 2: Linear regression analysis depicting the prediction of PEFR from age of the Nepalese males of the present study.

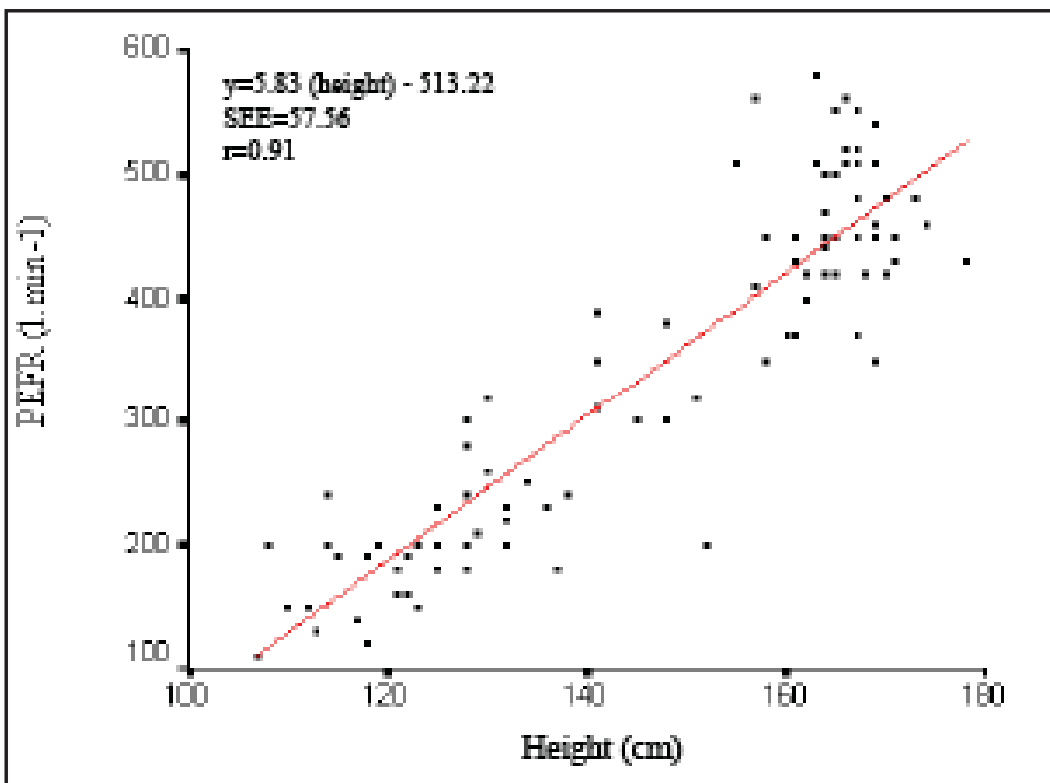

Fig 3: Linear regression analysis depicting the prediction of PEFR from height of the Nepalese males of the present study. 


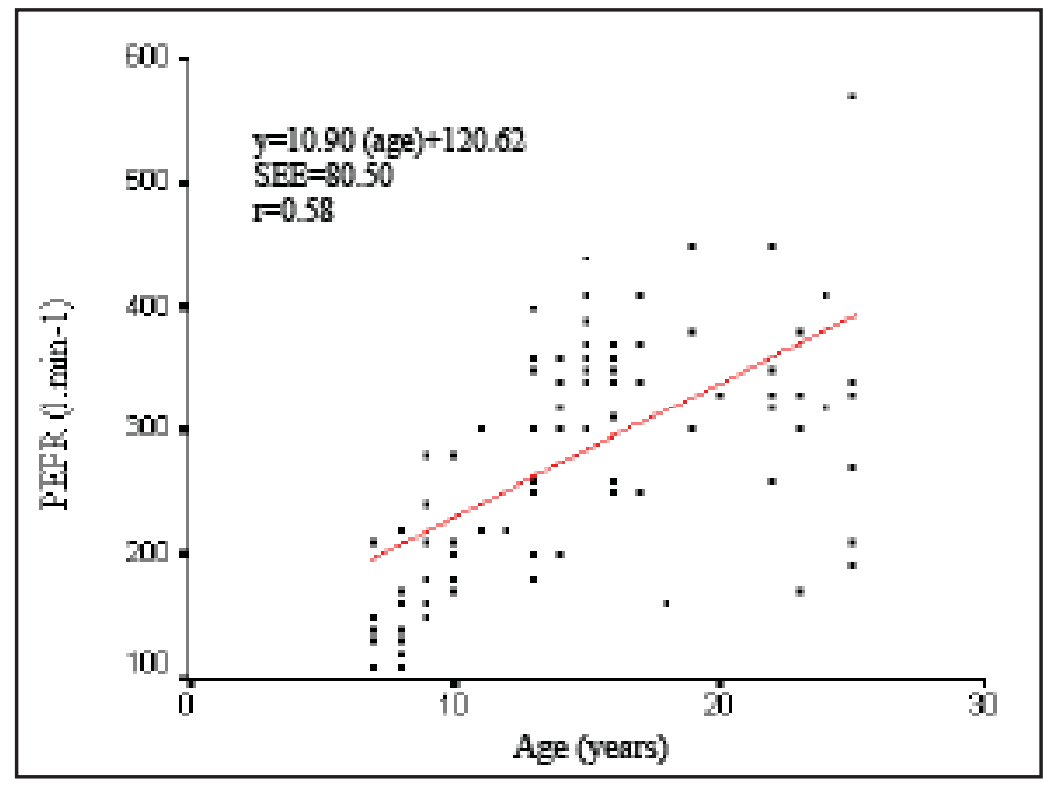

Fig 4: Linear regression analysis depicting the prediction of PEFR from age of the Nepalese females of the present study

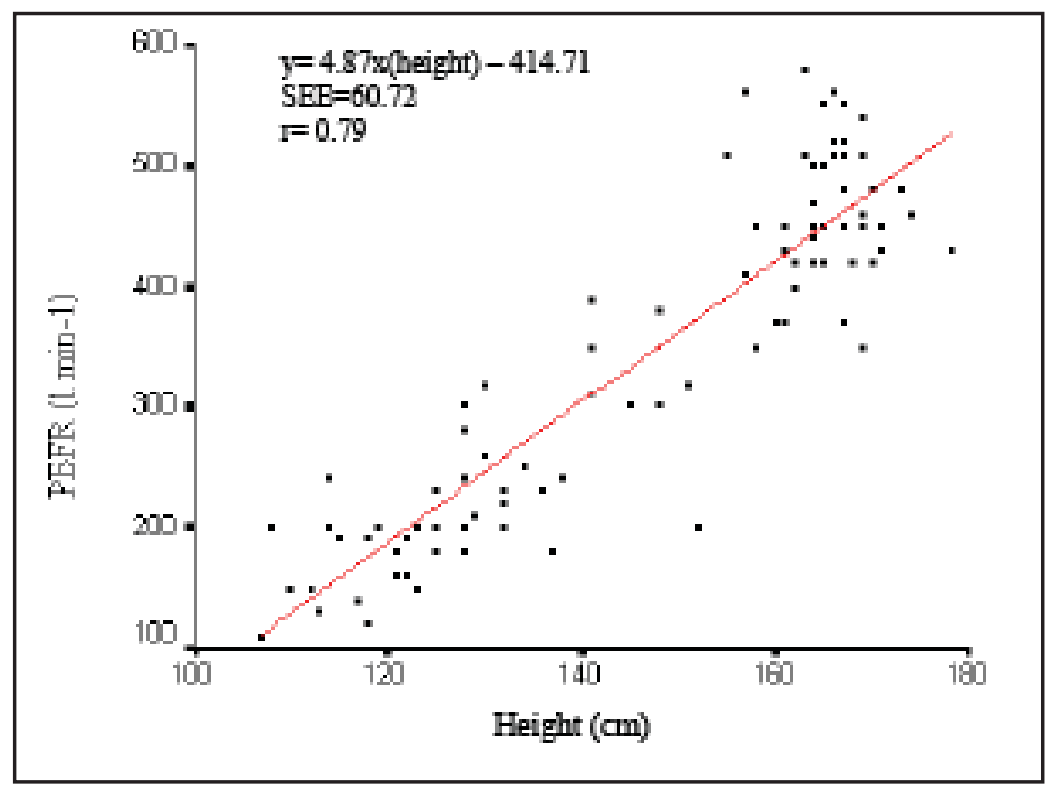

Fig 5: Linear regression analysis depicting the prediction of PEFR from height of the Nepalese females of the present study

\section{Discussion}

PEFR measurement by peak flow meter is an easy way to assess lung capacity and ventilatory functions of the subjects. The lung function tests including PEFR are influenced by various factors such as age, body size, physical activity, and environmental condition ethnicity etc. ${ }^{5,6,8}$. The subjects included in the present study were from the same place with almost same socio-economic status. On the other hand they all were non-smokers and sedentary people. So, the age wise and sex wise comparison of PEFR and physical characteristics were done.
In the present study the mean PEFR value of male were found to be $350.3( \pm 135.0) 1 . \mathrm{min}^{-1}$ while that of female were $280.2( \pm 98.77) 1 . \mathrm{min}^{-1}$ (Table 1). Age wise comparison of PEFR of the subjects of the present study with that of their Indian counterparts revealed that PEFR values of Nepalese children and young adults were higher as compared to South Indian children of Comboitre may be due to the environmental pollution as it is an industrial town with significant air pollution ${ }^{15}$, nevertheless subjects of our study were from Pokhara, a green and clean city of Nepal. Not only this, in the 
present study subjects was all non-smokers but in previous study among south Indians, smokers have not been excluded unless they admitted to chronic expectoration. Smoking habits and air pollutions also decreases the respiratory functions is a well established fact $^{10,14,16}$

The PEFR values in Nepalese males were comparable with Nigerian counterparts but in the Nepalese females PEFR values were found to be lesser than those of Nigerian females ${ }^{17}$. The PEFR values of the present study are higher than that of children of Thailand (5-15 years $)^{5}$.

The PEFR values of Nepalese males of the present study were found to be higher as compared to their females' counterparts. These findings are well corroborated with the other findings ${ }^{5,18,19}$. But when subjects were categorized into different age groups (Table 4 and Fig 1), it was interestingly noted that at preadolescence time, PEFR are almost comparable in both the sexes but after puberty males attained significantly higher values than females. This finding also corroborates well with other studies ${ }^{17,19}$. One study in Nigeria showed that PEFR was similar in both males and females up to 16 years of age ${ }^{17}$. In addition Sharma et al ${ }^{20}$ also reported that no significant difference were seen in any lung functions including PEFR in males and females in India up to 13 years of age but after that males attained higher values.

The trend of PEFR values with development of the age was also studied (Table 2, 3 and Fig.1). It was interestingly noted that Nepalese male's PEFR value increased significantly with the advancement of age up to 20 years of age after that PEFR did not increase. On the other hand females showed significant PEFR increment with the advancement of age up to 15 years only and then after PEFR did not improve significantly.

The plateau in PEFR (which was seen in Nepalese males after age of 20 years and in females after age of 15 years) may be due to cessation of growth in height. It was confirmed by the present study itself that height, weight, BSA did not change significantly in males at the age groups 16-20 and 21-25 years (Table 2). On the other hand, in females- height, weight, BSA did not change significantly at the age groups 11-15, 16-20 and 21-25 years (Table 3 ). These findings were similar to the findings of other studies, where such plateau was reported in females after 15 years but not in males. As females' growth stops earlier than males, the plateau in PEFR was also seen earlier in females than males ${ }^{15,21}$. It was also observed that age was positively and significantly $(p<0.01)$ correlated with PEFR in both the sexes, which corroborated well with other studies ${ }^{17,18,22,23}$.
It was observed that BMI was positively and significantly correlated with PEFR but WHR \& WTR are negatively and significantly correlated with PEFR. Body mass index (BMI), which is an important variable to measure overweight of the subjects ${ }^{24}$, was significantly $(\mathrm{P}<0.01)$ and positively correlated with PEFR in both males and females of the present study when age was partialed out. On the other hand WHR and WTR, which are the important indices to measure central obesity, were significantly $(\mathrm{P}<0.01)$ but negatively correlated with PEFR when BMI was controlled. So, it is obvious that central obesity measured by WHR and WTR influenced PEFR of the subjects. Physical activity improves fat distribution in the body. So, central obesity reflected less physical activity pattern of the subjects of the present study. Therefore, it can be predicted that less physical activity reduced PEFR. Body mass Index (BMI) was positively correlated with PEFR. BMI $\geq 25$ $\mathrm{kg} / \mathrm{m}^{2}$ also indicates over-weight-obesity pattern of the people ${ }^{24}$ as more WHR and WTR does (WHO, 1995). But in the present study, unlike WTR and WHR, BMI was positively correlated with PEFR, which was due to the fact that our subjects were in growing age and mean BMI of every age group were found to be $<25 \mathrm{~kg} / \mathrm{m}^{2}$.

Age of the subjects was significantly $(\mathrm{p}<0.01)$ correlated with PEFR even when BMI was controlled. Height of the subjects was found to be significantly correlated with PEFR when weight was partialed out but weight of the subjects was not significantly correlated when height was partialed out. So, it can be easily understood from the above findings that height is the main factor which may influence PEFR but not the weight. The present findings that PEFR correlated best with age and height corroborated well with others ${ }^{25,26}$. Thus, a prediction equation by which PEFR can be estimated from age or height in Nepalese population of age 5 to 25 years was established, which are as follows:

$$
\begin{aligned}
& \text { For male: } \\
& \text { PEFR }=22.42 \times \text { Age }(\text { years })+25.15 \\
& \text { PEFR }=5.83 \times \text { Height }(\mathrm{cm})-513.22 \\
& \text { For Females: } \\
& \text { PEFR }=10.90 \times \text { Age }(\text { years })+120.62 \\
& \text { PEFR }=4.87 \times \text { Height }(\mathrm{cm})-414.71
\end{aligned}
$$

\section{Acknowledgements}

Authors are grateful to the professor S.K. Dham, Dean, MCOMS and CEO, MEMG, Pokhara, Nepal for his necessary help to carry out the present study. Authors are also thankful to the volunteers for the present study for their cooperation to complete this study. 


\section{References}

1. Hutchinson R, Schwash M. Hutchinson's clinical methods, $21^{\text {st }}$ Edition. Harcour publisher limited, 2002: 60 .

2. Pocock G, Christopher DR. Human Physiologythe basis of medicine. Oxford university press, 1999: 337.

3. Wright BM, Mc Kerrow CB. Maximum Forced Expiratory Flow as a measure of ventilatory capacity. British Med J 1959; 2:1041-7.

4. Singh HD, Peri S. Peak expiratory flow rates in South Indian adults. Indian J Physiol Pharmacol. 1979; 23(4): 315-20.

5. Benjaponpitak S, Direkwattanachai C, Kraisarin C, Sasisakulporn C. Peak expiratory flow rate values of students in Bangkok. J Med Assoc Thai. 1999; 82(Suppl.): 137-43.

6. Srinivas P, Chia YC, Poi PJ, Ebrahim S. Peak expiratory flow rate in elderly Malaysians. Med J Malaysia. 1999; 54(1): 11-21.

7. Raju PS, Prasad KV, Ramana YV, Murthy KJ. Pulmonary function tests in Indian girls-prediction equations. Indian J Pediatr. 2004; 71(10): 893-97.

8. Raju PS, Prasad KV, Ramana YV, Balakrishna $\mathrm{N}$, Murthy KJ. Influence of socioeconomic status on lung function and prediction equations in Indian children. Pediatr Pulmonol. 2005; 39(6):528-36.

9. Prasad BK, Sahay AP, Singh AK. Smoking women and their lung function test. Kathmandu Univ Med. J 2003; 2 (2): 142-44.

10. Subhashini AS, Satchidhanandam N. Maximal expiratory flow volume curve in Quarry workers. Indian J Physiol Pharmacol. 2002; 46(1): 78-84.

11. Hussain S, Mohiuddin M, Shkeel Ur Rehman M, Rafiq A, Ahmed MA. PEFR in cement pipe factory workers. Indian J Physiol Pharmacol. 1999 Jul; 43(3): 405-6.

12. Rasheed BMA, Hussian K, Hussain S. PEFR in relation to phases of pregnancy. Indian J Physiol Pharmacol. 2000; 44(4):511-2.

13. Agarwal AN. Measurement of interpretation of peak expiratory flow. Indian J Physiol Pharmacol. 1998; 42(4): 567-68.

14. Debray P, Misra J, Ghosh C. Peak expiratory flow rate and cardio-respiratory fitness of Bengali workers exposed to dust and plant source particulate matters. Indian J Com Med. 2002; 27(4): 171-6.
15. Jepegnanam V, Amirtharaj G, Sulochana, Damodarasamy, Rao VM. Peak expiratory flow rate in a random healthy population of Coimbatore. Indian J Physiol Pharmacol. 1996; 40(2): 127-33.

16. Geetha B, Nair RH, Kesavachandran C, Chandy $\mathrm{S}$, Shashidhar S. Pulmonary function in workers of fertilizer and chemical industry. Indian $\mathrm{J}$ Physiol Pharmacol. 2001; 45(2): 215-21.

17. Jaja SI, Fagbenro AO. Peak expiratory flow rate in Nigerian school children. Afr J Med Med Sci. 1995; 24(4): 379-84.

18. Aundhakar CD, Kasliwal GJ, Yajurvedi VS, Rawat MS, Ganeriwal SK, Sangam RN. Pulmonary function tests in school children. Indian J Physiol Pharmacol. 1985; 29(1): 1420.

19. Nair RH, Keshavachandran C, Sanil R, Sreekumar R, Shashidhar S. Prediction equation for lung function in south-Indian children. Indian J Physiol Pharmacol. 1997; 41(4): 390-6.

20. Sharma PP; Gupta P; Deshpande R; Gupta P. Lung function values in healthy children (10-15 years). Indian J Pediatr. 1997; 64(1): 85-91.

21. Pande JN, Mohan A, Khilnani S, Khilnani GC. Peak expiratory flow rate in school-going children. Indian J Chest Dis Allied Sci. 1997; 39(2): 87-95.

22. Olanrewaju DM. Spirometric standards for healthy Nigerian children and adolescents. East Afr MedJ 1991; 68(10): 812-9.

23. Chia SE, Wang YT, Chan OY, Poh SC. Pulmonary function in healthy Chinese, Malay and Indian adults in Singapore. Ann Acad Med Singapore 1993; 22(6): 878-84.

24. World Health Organization Expert committee. The physical status. The use and interpretation of anthropometry. Geneva, Switzerland: World Health Organization; 1995: Technical Report Series 854.

25. Singh HD, Peri S. Peak expiratory flow rates in South Indian adults. Indian J Physiol Pharmacol. 1979; 23(4): 315-20.

26. Mengesha YA, Mekonnen Y. Spirometric lung function tests in normal non-smoking Ethiopian men and women. Thorax. 1985; 40(6): 465-8. 